\title{
Atypia and Differential Diagnosis in Cellular Blue Nevi: Clinicopathological Study of 21 Cases
}

\author{
Hücresel Mavi Nevuslarda Atipi ve Ayırıcı Tanı: \\ 21 Olgunun Klinikopatolojik Değerlendirilmesi
}

\author{
Banu YAMAN, Gülşen KANDíLOĞLU, Banu SARSIK KUMBARACI, Taner AKALIN
}

Department of Pathology, Ege University Faculty of Medicine, IZMIR, TURKEY

\begin{abstract}
Objective: Cellular blue nevus differs from the classic blue nevus with characteristics such as large size, cellularity, intense pigmentation, and growing pattern with subcutaneous infiltration. It is a dermal melanocytic tumor that can be confused with melanoma due to the atypia it may contain.
\end{abstract}

Material and Method: Hematoxylin-eosin and MIB-1 stained slides of 21 cases diagnosed between 2000-2014 were re-evaluated. In order to attract attention to this rare lesion, 21 cases are presented with the clinical and above-mentioned histopathological findings.

Results: Thirteen (61.9\%) cases were females and eight (38.1\%) were male. The mean age was 25.4 (2-73). The most frequent localization was the sacral and gluteal region (11 cases). The mean diameter was $14.4 \mathrm{~mm}(4-60 \mathrm{~mm})$. From the parameters defined to assess the atypia, ulceration was identified in four cases. Prominent cellularity and subcutaneous infiltration were seen in three and 16 cases, respectively. Mitosis was seen in six tumors. Immunohistochemically, MIB- 1 was present in two cases as $3 \%$ and $2 \%$ respectively, while in others it was $1 \%$ or less. Although there is no precise definition for the "atypical cellular blue nevus", five patients were assessed as atypical cellular blue nevus (a case with infiltrative development of six $\mathrm{cm}$ tumor diameter, two cases with two mitosis and a MIB-1 index 3\% and $2 \%$, a case with one mitosis and confluent development and a case with one mitosis in addition to focal necrosis areas). No lymph node and/or distant metastasis was observed during follow-up.

Conclusion: We think it is more important to rule out the possibility of conventional melanoma in cellular blue nevus with exaggerated morphological findings alongside low proliferative activity rather than to determine the atypia.

Key Words: Cellular blue nevus, Differential diagnosis, MIB-1 protein

(Turk Patoloji Derg 2015, 31:89-94)

Received : 16.11.2014 Accepted : 23.12.2014

\section{ÖZ}

Amaç: Hücresel mavi nevus, hücresel görüntüsü, subkutanöz infiltrasyon yapan gelişim paterni, yoğun pigmentasyon ve büyük boyut gibi bulguları ile klasik mavi nevustan farklılıklar gösteren ve içerebildiği atipi kriterleri nedeni ile melanomla karışabilen dermal melanositik tümördür.

Gereç ve Yöntem: Merkezimizde 2000-2014 yılları arasında değerlendirdiğimiz 21 olgunun hematoksilen-eosin ve MIB-1 boyalı preparatları tekrar gözden geçirildi. Görece az olan bu lezyona dikkat çekmek amacı ile 21 olgu klinik ve yukarıda tanımlanan histopatolojik bulguları eşliğinde sunulmaktadır

Bulgular: Olguların 13'ü $(\% 61,9)$ kadın, sekizi $(\% 38,1)$ erkek olup yaş ortalaması 25,4 idi (2-73). En sık yerleşim yeri sakral ve gluteal bölge (11 olgu) idi. Tümör boyut ortalaması 14,4 mm idi (4-60 mm). Son yıllarda tanımlanmış atipik değişiklikleri değerlendirmek için incelenen parametrelerden ülser dört tümörde, konfluent görüntü üç, subkutanöz yağ doku infiltrasyonu 16 , mitoz ise, altı tümörde saptand 1 . İmmunhistokimyasal incelemede MIB-1, iki olguda sırasıly \%3 ve $\% 2$, diğer olgularda ise $\% 1$ veya daha düşük bulundu. Kaynaklarda "atipik hücresel mavi nevus" ile ilgili kesin tanımlama bulunmamakla birlikte serimizde saptanan beş olgu (altı $\mathrm{cm}$ çaplı infiltratif gelişim gösteren olgu, iki mitoz ve sırası ile MIB-1 \%3-\%2 saptanan iki olgu, bir mitoz yanısıra konfluent gelişim gösteren olgu ve odaksal nekroz alanları yanısıra bir mitoz saptanan olgu) atipik hücresel mavi nevus olarak değerlendirildi. Lenf nodu ve/veya uzak metastaz izlenmeyen olgularımızın takipleri hastalıksız olarak sürmektedir.

Sonuç: Hücresel mavi nevusların atipik olup olmadığını belirlemekten çok, abartılı morfolojik bulgular sergileyebilen ancak proliferatif aktivitesi düşük olgularda konvansiyonel melanom olasılığını ekarte etmenin daha önemli olduğunu düşünüyoruz.

Anahtar Sözciukler: Hücresel mavi nevus, Ayırıcı tanı, MIB-1 protein
Correspondence: Banu YAMAN

Ege Üniversitesi Tip Fakültesi, Patoloji Anabilim Dalı,

35100, Bornova, IZZMIR, TURKEY

E-mail: drbanuyaman@yahoo.com Phone: + 902323903709 


\section{INTRODUCTION}

Blue nevi are dermal melanocytic proliferations containing cells similar to dendritic melanocyte precursors of embryonic neural crest origin (1). The nature and developmental biology of these melanocytic lesions are not clearly understood. It is therefore difficult to classify benign and malignant blue nevi and to differentiate them from other melanocytic lesions (2-9).

The blue nevus term was first used by Jadassohn for dark blue lesions of the skin but the lesion was first described in the literature by Max Tiéche in 1906 (10, 11). Blue nevi are commonly classified among dermal hamartomatous dendritic melanocytic lesions such as nevus of Ota and Ito $(1,11)$. The blue nevus group includes dendritic (classic) blue nevus, cellular blue nevus (CBN), and deep penetrating nevus (11). They can be blue or grey in the clinic according to the depth of the lesion and melanin content (11).

Cellular blue nevus differs from classic blue nevus with a cellular appearance, subcutaneous infiltration, intensive pigmentation and large size. It can be confused with melanoma due to the atypia criteria that may be present. The term was first used by Allen (12) in 1949 and it was described as a benign variant of blue nevus that could be confused with melanosarcoma due to its cellularity and intense melanin content. Other authors have reported that $\mathrm{CBN}$ is a benign neoplasm related to blue nevus but is not similar to melanoma $(1,11,13)$.

The atypical cellular blue nevus (ACBN) term is used for $\mathrm{CBN}$ that has atypical features and requires differentiation from malignant blue nevus. However, there is no consensus regarding the classification or definite diagnostic criteria of the $\mathrm{CBN}, \mathrm{ACBN}$, malignant $\mathrm{CBN}$ and malignant melanoma spectrum (1).

We aimed to present the clinical and histopathological data of our cellular blue nevus cases as they are less common blue nevi lesions and to reveal the common and different aspects when compared with our few atypical cellular blue nevus cases.

\section{MATERIAL and METHODS}

All blue nevus cases diagnosed between 2000 and 2014 at our pathology department were reviewed and 21 cases with cellular characteristics, such as larger size, prominent pigmentation, subcutaneous infiltration, and cellularity were included in the study. Seven of the cases included in the study were sent from various external centers for consultation with a diagnosis of malignant melanoma. Clinical data such as age of patient, localization and diameter of lesion were obtained from archival records of pathology department. Hematoxylin-eosin (H\&E) and MIB-1 stained slides belonging to all blocks of the cases were re-evaluated. The following parameters were assessed: ulceration, degree of pigmentation, confluence, growth pattern, and mitoses per millimeter. Most follow-up data was gathered via a telephone call.

\section{RESULTS}

There were 13 (61.9\%) females and 8 (38.1\%) males with a mean age of 25.4 (2-73) years. The most frequent localization was the sacral and gluteal region (11 cases). Mean tumor size was 14.4 (4-60) $\mathrm{mm}$. Two cases had combined nevus accompanied by a banal nevus component. One case had CBN with a sinus pilonidalis lesion at the sacral region.

The demographic characteristics of the cases and histopathological features of the lesions are presented in Table I.

Histopathological evaluation revealed surface ulceration in four cases. The lesion was in the form of dermal nodular lesion and bulges into the subcutaneous fat in all but one case. Expansive development and subcutaneous fat tissue invasion in the tumor was seen in 15 (71.4\%) cases while infiltrative development to surrounding tissues was found in one case (Figure 1A-D). Intensive cellularity was observed in three cases. The lesions consisted of ovalspindle cells, dendritic melanocytic cells and macrophages in various rates. The pigmentation, mostly observed in the macrophages, was quite intense (more than 75\%) in two cases and mild (less than 25\%) in six cases. Sclerosis areas were observed in addition to dendritic melanocyte clusters and melanophage groups constituting an alveolar pattern in some of the lesion. A markedly edematous stroma $(n=5)$, cystic areas $(\mathrm{n}=1)$ and rosette-like multinucleated giant cells $(n=1)$ were observed in a small number of cases.

Focal necrosis and one mitosis per square millimeter were found in a lesion on the gluteal area. Other atypia criteria were not observed. None of the case had marked cytological atypia or nuclear pleomorphism.

No mitosis was observed in 16 (72\%) cases, while there was one mitosis per square millimeter in four cases and two mitoses per square millimeter in two cases (Figure 2A-D). MIB-1 proliferating index were $3 \%$ and $2 \%$ in two cases and $1 \%$ or lower in the others on immunohistochemical investigation.

The mean follow-up period was 58.38 \pm 48.00 (9-179 months). No recurrence and/or metastasis were observed during follow-up.

\section{DISCUSSION}

Cellular blue nevus (CBN) is usually seen in adults under the age of 40 but can be seen at all ages. The incidence is higher in females $(7,11)$. The most frequent location is the gluteal and sacrococcygeal region but it can also be seen in the scalp, facial region and extremities. Genital tract, breast, subungual, intraocular and conjunctival CBN cases have also been reported $(1,7,8,11,14,15)$. 
Table I: The clinical and histopathological features of cases

\begin{tabular}{|c|c|c|c|c|c|c|c|c|c|c|c|c|}
\hline 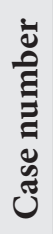 & 它 & $\underset{\pi}{\infty}$ & 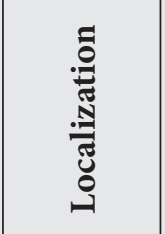 & 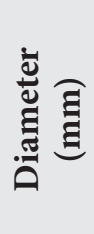 & 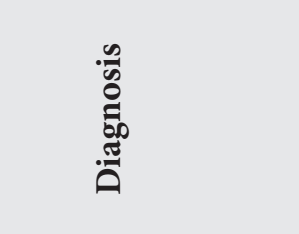 & & 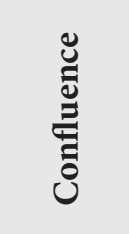 & 全 & 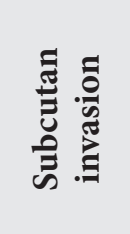 & 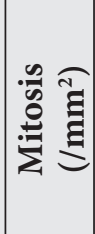 & 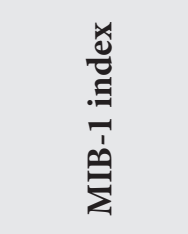 & 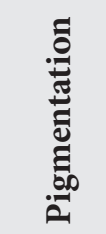 \\
\hline 1 & $\mathrm{~F}$ & 23 & forearm & 15 & $\begin{array}{l}\text { Combined CBN + } \\
\text { Compound Nevus }\end{array}$ & $(-)$ & $(-)$ & expansive & present & 1 & focally $<\% 1$ & $>25 \%$ \\
\hline 2 & M & 26 & back & 11 & $\begin{array}{l}\text { Combined CBN + } \\
\text { Intradermal Nevus }\end{array}$ & $(-)$ & $(-)$ & expansive & present & - & focally $<\% 1$ & $25 \%$ \\
\hline 3 & M & 30 & sacral & 13 & $\begin{array}{c}\text { CBN + Pilonidal } \\
\text { Sinus } \\
\end{array}$ & $(-)$ & $(-)$ & expansive & $(-)$ & - & $(-)$ & $>75 \%$ \\
\hline 4 & $\mathrm{~F}$ & 19 & sacral & 6 & $\mathrm{CBN}$ & $(-)$ & $(-)$ & expansive & present & - & $(-)$ & $<25 \%$ \\
\hline 5 & $\mathrm{~F}$ & 54 & gluteal & 5 & $\mathrm{CBN}$ & $(-)$ & $(-)$ & expansive & $(-)$ & - & focally $\% 1$ & $<25 \%$ \\
\hline 6 & $\mathrm{M}$ & 20 & hand & 9 & $\mathrm{CBN}$ & $(-)$ & $(-)$ & expansive & present & - & $(-)$ & $<25 \%$ \\
\hline 7 & $\mathrm{~F}$ & 30 & face & 10 & $\mathrm{CBN}$ & $(-)$ & $(-)$ & expansive & $(-)$ & - & $1 \%$ & $<25 \%$ \\
\hline 8 & $\mathrm{M}$ & 2 & knee & 10 & $\mathrm{CBN}$ & $(-)$ & $(-)$ & expansive & present & - & $2 \%$ & $>75 \%$ \\
\hline 9 & $\mathrm{M}$ & 9 & gluteal & 6 & $\mathrm{CBN}$ & $(-)$ & $(-)$ & expansive & present & - & $(-)$ & $>50 \%$ \\
\hline 10 & $\mathrm{~F}$ & 22 & gluteal & 15 & $\mathrm{CBN}$ & $(-)$ & $(-)$ & expansive & present & - & focally $<\% 1$ & $>50 \%$ \\
\hline 11 & $\mathrm{~F}$ & 21 & gluteal & 12 & $\mathrm{CBN}$ & $(-)$ & $(-)$ & expansive & present & 1 & focally $<\% 1$ & $>25 \%$ \\
\hline 12 & $\mathrm{~F}$ & 13 & knee & 10 & $\mathrm{CBN}$ & $(-)$ & $(-)$ & expansive & present & - & $(-)$ & $25 \%$ \\
\hline 13 & $\mathrm{~F}$ & 51 & gluteal & 4 & $\mathrm{CBN}$ & $(-)$ & $(-)$ & expansive & present & - & focally $<\% 1$ & $<25 \%$ \\
\hline 14 & $\mathrm{M}$ & 73 & abdomen & 15 & $\mathrm{CBN}$ & $(-)$ & present & expansive & $(-)$ & - & focally $<\% 1$ & $<25 \%$ \\
\hline 15 & $\mathrm{~F}$ & 30 & scalp & 20 & $\mathrm{CBN}$ & present & $(-)$ & expansive & present & - & $(-)$ & $25 \%$ \\
\hline 16 & M & 28 & sacral & 20 & $\mathrm{CBN}$ & present & $(-)$ & expansive & $(-)$ & - & focally $<\% 1$ & $>50 \%$ \\
\hline 17 & $\mathrm{~F}$ & 34 & gluteal & 20 & $\mathrm{ACBN}$ & $(-)$ & $(-)$ & expansive & present & 1 & focally $<\% 1$ & $>50 \%$ \\
\hline 18 & $\mathrm{M}$ & 17 & sacral & 20 & $\mathrm{ACBN}$ & present & $(-)$ & expansive & present & 2 & focally $\% 2$ & $>50 \%$ \\
\hline 19 & $\mathrm{~F}$ & 12 & gluteal & 14 & $\mathrm{ACBN}$ & present & present & expansive & present & 1 & $(-)$ & $<50 \%$ \\
\hline 20 & $\mathrm{~F}$ & 4 & arm & 7 & ACBN & $(-)$ & $(-)$ & expansive & present & 2 & $3 \%$ & $50 \%$ \\
\hline 21 & $\mathrm{~F}$ & 15 & vulva & 60 & ACBN & $(-)$ & present & infiltrative & present & - & $(-)$ & $>50 \%$ \\
\hline
\end{tabular}

CBN: Cellular Blue Nevus, ACBN: Atypical Cellular Blue Nevus.

Clinically, there is a pigmented nodular lesion with a size from a few millimeters to centimeters. Giant CBN cases larger than $10 \mathrm{~cm}$ have been reported in addition to the usual $1-2 \mathrm{~cm}$ lesions. The pigmentation may be blue-black $(1,7,11,14)$.

Our CBN lesions were mostly gluteal and sacral, as reported in the literature. The $6 \mathrm{~cm}$ vulvar lesion in a 15-year-old patient and the CBN together with a pilonidal sinus were examples of rare presentations among our patients.

Microscopically, the lesions are generally located in the superficial and mid dermis and can show invasion to the deep dermis and subcutaneous tissue. Most lesions have an expansive and regular border (1). Dendritic melanocytic cells and melanophages in various rates are observed among the oval-spindle cells. Sclerosis is frequently present and other findings such as myxoid change, hemorrhage and stromal hyalinization can be seen $(1,7,8,11)$. Mitosis is usually not seen or less than one per square millimeter $(8$, 11).

Cytologically, oval-spindle melanocytes are seen in cellular areas. The cells have a large and lightly pigmented-clear cytoplasm with vesicular nuclei. Multinucleated giant cells can be seen (1).

CBNs can exhibit very different histological appearances and can therefore be confused with melanomas. A small number of melanoma cases on a CBN background have been reported in the literature $(11,16)$. CBN is not common and CBNrelated melanoma cases are very rare, making it difficult for pathologists and clinicians to elucidate the biological nature and malignancy potential of these cases (2). 

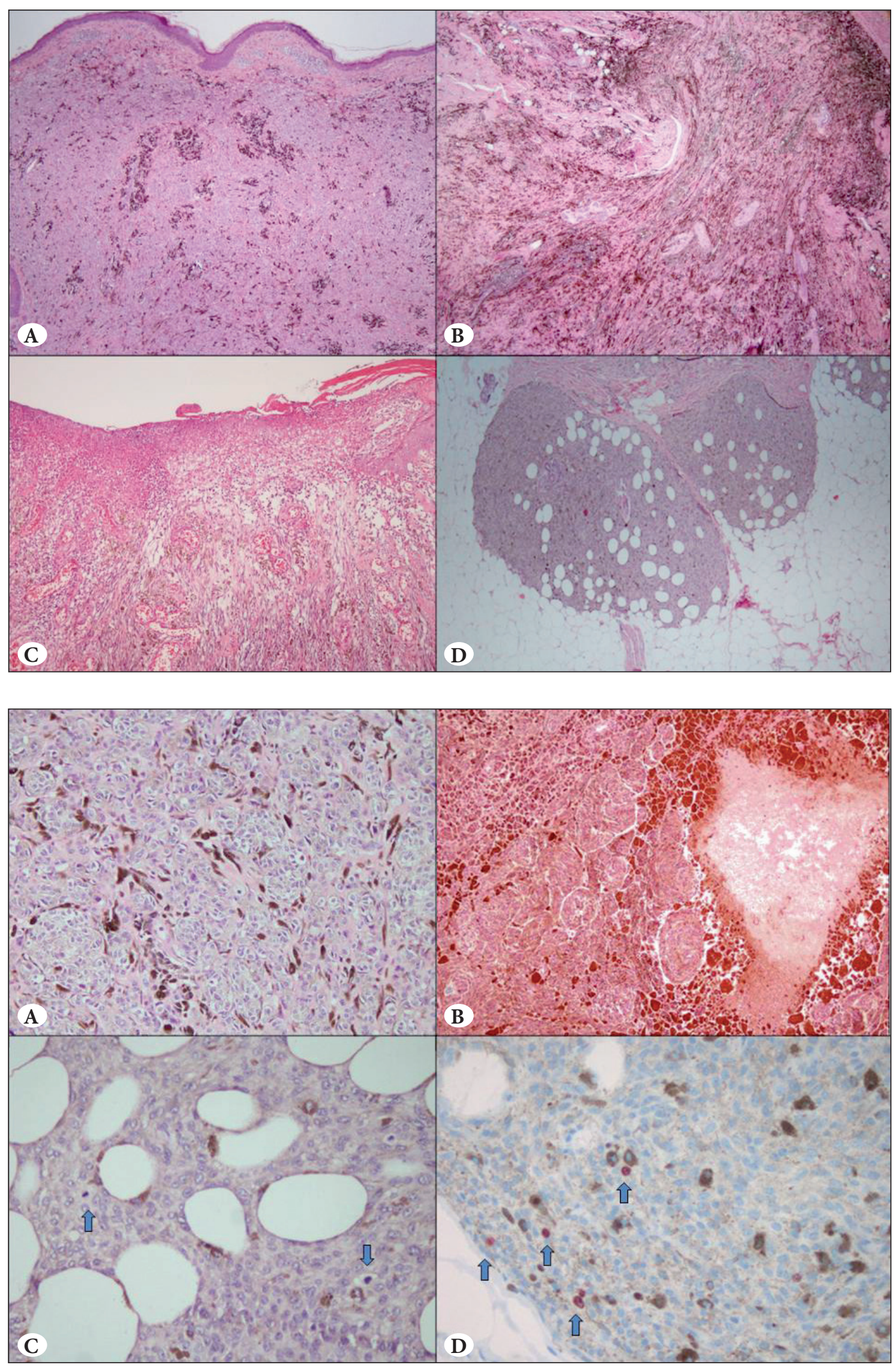

Figure 1: A) Dermal localized cellular blue nevus (H\&E; $\mathrm{x} 40$ ),

B) Intensive pigment content (H\&E; x100), C) Ulcer on the surface (H\&E; x100), D) Expansive growth pattern into subcutaneous tissue (H\&E; x100).
Figure 2: A) Nevus cells of epithelioid appearance in cellular blue nevus (H\&E; x200),

B) Presence of focal necrosis

(H\&E; x 200),

C) Two mitoses in one field

(H\&E; x400),

D) MIB-1 positivity (MIB-1; x400). 
Certain blue nevus cases with CBN characteristics and some additional atypia findings that have not been identified as melanoma have been named atypical cellular blue nevus $(\mathrm{ACBN})(3,8,9,17)$. Other authors have named these lesions CBN-like melanocytic tumor with local aggressive features or unclear malignant potential $(6,18)$. ACBN is frequently seen in the gluteal and sacral region in young and middle-age adults $(3,8,11)$.

ACBN diagnostic criteria are not yet clear. Atypia criteria can include asymmetry, hypercellular areas, focal cytological atypia and rare mitoses $(<2 / \mathrm{mm} 2)$. Many authors report that focal necrosis can be observed but no atypical mitosis is seen $(3,8,9,11,17,18)$. Some authors feel that atypical mitotic activity and necrosis are releated to malignant blue nevi (9). A large size $(5-10 \mathrm{~cm})$, vascular invasion, marked nuclear pleomorphism and more than 3 mitoses per $\mathrm{mm}^{2}$ have been identified as atypia criteria for malignant blue nevi $(1,19,20,21)$. However, these criteria can be present both in CBN and melanoma cases and cannot be used as auxiliary criteria for the differential diagnosis (1).

Murali et al. (11) reported that they identified lesions with isolated mitosis or necrosis as atypical CBN when other atypia features such as intensive cellularity, nuclear atypia, hyperchromasia, and expansive growth were absent. However, they also reported that the biological behavior could not be predicted due to insufficient morphological signs but the risk of aggressive behavior risk was low.

There is therefore no clear consensus regarding diagnostic criteria for ACBN. This leads to poor consistency in the classification of these lesions among dermatopathologists (1). Barnhill et al (2) showed that there were inconsistencies regarding the biological nature definition and identification of CBN cases by histopathologists especially when atypical characteristics were present (ACBN) in their study of 26 melanocytic cases.

When we evaluated our cases using the atypia criteria identified above, five cases (one case with infiltrative development of six $\mathrm{cm}$ diameter, two cases with two mitoses and a MIB- 1 index $3 \%$ and $2 \%$, one case with one mitosis and confluent development and one case with one mitosis in addition to focal necrosis areas) were consistent with atypical CBN.

There are reports that ACBN does not recur or metastasize (9) while others state that it can relapse and has a more aggressive course, especially following incomplete excision (18). Some authors have diagnosed CBN cases with tumors deposits in lymph nodes as ACBN (22).

Lymph node excision had not been performed in our cases. We did not observe any recurrence and/or metastasis during the follow-up of the five cases with atypical features or in the other cases.
Cases with atypical features should be excised totally with intact surgical borders and followed-up closely for nodal-distant spread as well as local recurrence due to the inconsistencies in the ACBN criteria and thus the malignancy potential definition in the literature as defined above.

More studies supported with molecular researches and long-term follow-up are required to clearly determine the morphological criteria affecting biological behavior in cellular blue nevi.

In conclusion, cellular atypia and proliferative activity is usually low in CBNs although they may have a prominent morphological appearance with intensive pigment with a quick look, and do not create a differential diagnosis problem for experienced dermatopathologists. Cases with atypical features indicating melanoma can create difficulties at the differential diagnosis but there are no definite criteria. The use of the term "Atypical cellular blue nevus" is not commonly accepted if there are only minor morphological deviations. We did not see any recurrence during followup in our "ACBN" cases with such minor deviations. This finding indicates that these cases are biologically closer to cellular blue nevus.

\section{REFERENCES}

1. Zembowicz A, Phadke PA. Blue nevi and variants: An update. Arch Pathol Lab Med. 2011;135:327-36.

2. Barnhill RL, Argenyi Z, Berwick M, Duray PH, Erickson L, Guitart J, Horenstein MG, Lowe L, Messina J, Paine S, Piepkorn MW, Prieto V, Rabkin MS, Schmidt B, Selim A, Shea CR, Trotter MJ. Atypical cellular blue nevi (cellular blue nevi with atypical features): Lack of consensus for diagnosis and distinction from cellular blue nevi and malignant melanoma ("malignant blue nevus"). Am J Surg Pathol. 2008;32:36-44.

3. Avidor I, Kessler E. "Atypical" blue nevus-a benign variant of cellular blue nevus. Dermatologica. 1977;154:39-44.

4. Elder DE, Murphy GF. Melanocytic tumors of the skin. Atlas of tumor pathology, Washington: AFIP; 1990.

5. Goldenhersh MA, Savin RC, Barnhill RL, Stenn KS. Malignant cellular blue nevus. Case report and literature review. J Am Acad Dermatol. 1988;19:712-22.

6. Leopold JG, Richards DB. Cellular blue nevi. J Path Bact. 1967;94:245-7.

7. Rodriguez HA, Ackerman LV. Cellular blue nevus. Clinicopathologic study of forty-five cases. Cancer. 1968;21:393405.

8. Temple-Camp CRE, Saxe N, King H. Benign and malignant cellular blue nevus. A clinicopathological study of 30 cases. Am J Dermatopathol. 1988;10:289-96.

9. Tran TA, Carlson JA, Basaca PC, Mihm MC. Cellular blue nevus with atypia (atypical cellular blue nevus): A clinicopathologic study of nine cases. J Cutan Pathol. 1998;25:252-8. 
10. Tieche M. Uber benigne Melanome ("Chromatophorome") der Haut- "blaue Naevi". Virchows Arch Pathol Anat. 1906;186:21229.

11. Murali R, McCarthy SW, Scolyer RA. Blue nevi and related lesions: A review highlighting atypical and newly described variants, distinguishing features and diagnostic pitfalls. Adv Anat Pathol. 2009;16:365-82.

12. Allen AC. A reorientation on the histogenesis and clinical significance of cutaneous nevi and melanomas. Cancer. 1949;12:28-56.

13. Lever WF. Histopathology of the Skin. Philadelphia: JB Lippincott Co; 1961:595-7.

14. Causeret AS, Skowron F, Viallard AM, Balme B, Thomas L. Subungual blue nevus. J Am Acad Dermatol. 2003;49:310-2.

15. Speakman JS, Phillips MJ. Cellular and malignant blue nevus complicating oculodermal melanosis (nevus of Ota syndrome). Can J Ophthalmol. 1973;8:539-47.

16. Aloi F, Pich A, Pippione M. Malignant cellular blue nevus: A clinicopathological study of 6 cases. Dermatology. 1996;192:3640.
17. Maize JC Jr, McCalmont TH, Carlson JA, Busam KJ, Kutzner H, Bastian BC. Genomic analysis of blue nevi and related dermal melanocytic proliferations. Am J Surg Pathol. 2005;29:1214-20.

18. Elder DE, Murphy GF. Malignant tumors (melanomas and related lesions). In: Rosai J, editor. Atlas of tumor pathology: Melanocytic tumors of the skin. Washington, DC: Armed Forces Institute of Pathology; 1991:177-85.

19. Zembowicz A, Mihm MC. Dermal dendritic melanocytic proliferations: An update. Histopathology. 2004;45:433-51.

20. Spatz A, Zimmermann U, Bachollet B, Pautier P, Michel G, Duvillard P. Malignant blue nevus of the vulva with late ovarian metastasis. Am J Dermatopathol. 1998;20:408-12.

21. Mehregan DA, Gibson LE, Mehregan AH. Malignant blue nevus: A report of eight cases. J Dermatol Sci. 1992;4:185-92.

22. Sterchi JM, Muss HB, Weidner N. Cellular blue nevus simulating metastatic melanoma: Report of an unusually large lesion associated with nevus-cell aggregates in regional lymph nodes. J Surg Oncol. 1987;36:71-5. 